\title{
Bulk-carbonate and belemnite
}

\section{carbon-isotope records across the}

Pliensbachian-Toarcian boundary on the northern margin of Gondwana (Issouka, Middle Atlas, Morocco)

\author{
Ait-Itto, F-Z
}

http://hdl.handle.net/10026.1/8648

10.1016/j.palaeo.2016.11.014

Palaeogeography, Palaeoclimatology, Palaeoecology

Elsevier BV

All content in PEARL is protected by copyright law. Author manuscripts are made available in accordance with publisher policies. Please cite only the published version using the details provided on the item record or document. In the absence of an open licence (e.g. Creative Commons), permissions for further reuse of content should be sought from the publisher or author. 
1 Carbon isotope stratigraphy and belemnite isotope records across the Pliensbachian-

2 Toarcian boundary, of the Northern Margin of Gondwana, Issouka, Middle Atlas,

3 Morocco

5 Ait-Itto F.-Za, Ait Addi A, Price G.D. ${ }^{\text {b }}$, Samar, L. ${ }^{c}$, Chafiki D. ${ }^{a}$, Mannani, I. ${ }^{a}$

${ }^{a}$ Cadi Ayyad University, Faculty of Sciences and Techniques, Geosciences and Environmental research's Laboratory, P.O. Box 549, Marrakech-Morocco. Emails: f.aititto@gmail.com; aitaddiabdellah@gmail.com

${ }^{b}$ School of Geography, Earth and Environmental Sciences Plymouth University, Plymouth, Devon, PL4

$118 A A, U K$

'SONATRACH, Algeria

ABSTRACT

The data presented here provide the first high resolution investigation of carbon isotope and geochemical analyses derived from the Pliensbachian-Toarcian boundary, of Issouka, Middle Atlas, Morocco. The isotope data recorded in micrite reveal a stepwise negative carbon isotope excursion with values dropping to $-1.8 \%$ within the Polymorphum Zone. This excursion coincides with major marine biological changes and extinctions and corresponds with European records supporting the assertion that the excursion is global in origin. The Issouka section is relatively expanded compared to other well-studied European sections. The excursion at the Pliensbachian-

22 Toarcian boundary also shows several similarities with the negative Early Toarcian event. In contrast, carbon isotope values derived from coeval belemnites show positive values. The 
24 belemnite $\delta^{13} \mathrm{C}$ data presented here suggests spatial heterogeneity in the Early Jurassic ocean.

25 Overturning or upwelling of a stratified water mass, is inconsistent with our data, as it requires the 26 belemnites to have lived elsewhere and only later migrated into the Middle Atlas area where they

27 became fossilized. The oxygen isotope values from belemnite calcite show no distinct trend across

28 the event, indicative of either no significant change in temperatures or change in seawater $\delta^{18} \mathrm{O}$.

29 We suggest the introduction of any light carbon (e.g. a volcanogenic) source must have resulted in 30 spatial variability in the $\delta^{13} \mathrm{C}$ of the dissolved inorganic carbon of seawater. Alternatively, a regional

31 change in the source of the carbonate carrying the isotope signal, could lead to a negative shift in

32 the $\delta^{13} C_{\text {micrite }}$ signature without any relation to variations in the global carbon isotope trend.

34 Keywords

35 Palaeoenvironment, stratigraphy, Early Jurassic, $\delta^{13} \mathrm{C}, \delta^{18} \mathrm{O}$ 


\section{$38 \quad 1 . \quad$ Introduction}

The Early Jurassic was marked by extreme environmental changes (Cohen et al., 2004; 2007;

Hesselbo et al., 2007), characterized by major marine biological changes and extinctions at a global

scale (Little and Benton, 1995; Harries and Little, 1999; Cecca and Macchioni, 2004; Wignall and

Bond, 2008), and pronounced negative carbon isotope shifts recorded in marine carbonates and

organic matter, brachiopods, biomarkers and fossil wood (Hesselbo et al., 2000; 2007; Suan et al.,

2008, Hermoso et al., 2009; Littler et al., 2010; Sandoval et al., 2012; Montero-Serrano et al., 2015;

Krencker et al., 2015). The increasing number of high resolution studies has led to smaller scale

events being recognised during the Early Sinemurian (Porter et al., 2014) and at the Pliensbachian-

Toarcian boundary (Bodin et al., 2010; Littler et al., 2010). In order to further document these

palaeoenvironmental changes, the Late Pliensbachian-Early Toarcian of the Middle Atlas rift basin

of Morocco, was investigated. Previous investigations in the region have mainly focused on the

platform drowning event observed in the Middle Atlas Basin at the Pliensbachian-Toarcian

boundary (Benshili, 1989; Ruget and Nicollin, 1997; Blomeier and Reijmer, 1999; Lachkar et al.,

2009; Dera et al., 2009), and a few studies have characterized palaeoenvironmental change using

benthic foraminiferal assemblages (Bejjaji, 2007, Bejjaji et al., 2010; Reolid et al., 2013).

The aim of this research is to present a new high-resolution investigation of carbon isotopes

55 from the Middle Atlas in order to contribute to an understanding of the palaeoceanographic

conditions during the Pliensbachian-Toarcian boundary in the deeper water zones of the Tethyan

realm. A concurrent analysis of the oxygen- and carbon-isotope analysis of belemnites has also 
carbon isotope stratigraphy as well as help elucidated the mechanisms behind the purported

61 isotope event.

\section{Geological Setting}

Both the opening of the north Atlantic and western Tethys during the early Mesozoic and the collision of Africa and Europe during the middle Cenozoic (Michard, 1976) influenced the geological history of Morocco. These two geological events formed the Atlas System as well as the Rif Mountains. Crustal extension was initiated in the Late Triassic and lasted until the earliest Jurassic. This was followed by renewed crustal extension in Toarcian times (Laville et al., 2004) which led to the formation of the fault-bounded mosaic of Middle and High Atlas troughs(Studer and Du Dresnay, 1980). The Middle Atlas of Morocco is structurally dominated by four NE-SW trending anticlines and is mainly constituted of Lower and Middle Jurassic formations (Du Dresnay, 1971; Benshili, 1989; Bejjaji, 1994; Sabaoui, 1998, Souhel et al., 2000, El hammichi et al., 2008;

Bejjaji et al., 2010). The Pliensbachian-Toarcian transition coincides with a dislocation of the Lower Jurassic carbonate platform (Blomeier and Reijmer, 1999; Lachkar et al., 2009, Dera et al., 2009;

Bodin et al., 2016) with Toarcian deposits dominated by marls lying upon Upper Pliensbachian shallow marine limestones and calcareous marls. At the top of the sequence, these deposits are overlain by Aalenian-Lower Bajocian marls and calcareous marls (Bejjaji et al., 2010).

The palaeogeography of the Middle Atlas consists of relatively deep marine conditions

(Fig.1) in the center and shallows towards the northern and southern basin margins (Du Dresnay, 1971; Souhel et al., 2000; Bodin et al., 2010). The study area during the Early Toarcian was located at a palaeolatitude of $\sim 20^{\circ} \mathrm{N}$ (Bassoulet et al., 1993). The sedimentary evolution and palaeogeographic differentiation is controlled by tectonic activity, combined with the rate of sedimentation and global eustatic variations (Benshili, 1989; Ruget and Nicollin, 1997). The rapid 
transition from shallow marine carbonates to hemipelagic marls has been taken to reflect a major

deepening phase across the entire Middle and High Atlas area (Ettaki et al. 2000; El Arabi et al.

2001; Wilmsen and Neuweiler 2008). This drowning episode is linked with the eustatic sea-level

rise of the Early Toarcian in Europe and Africa, described by many workers (e.g. Hallam, 1997;

Hardenbol et al., 1998). Coincident with this drowning episode, a substantial increase of seawater

temperatures in the Early Toarcian has been inferred, reaching a maximum during the Falciferum

Zone, documented using the oxygen isotope composition and the $\mathrm{Mg} / \mathrm{Ca}$ ratio of belemnites and

brachiopods from NW European regions (e.g. Jenkyns et al., 2002; Rosales et al., 2004 ; Suan et al.,

2010; Dera et al., 2011; Harazim et al., 2013; Ferreira et al., 2015).

\section{Methods}

The samples for this study were obtained from the Late Pliensbachian-Early Toarcian

Issouka section, within the Middle Atlas, Morocco (Figs. 1, 2). The studied section was logged and samples for analysis were collected from selected intervals throughout the section. Bulk samples were dominated by wackestone and carbonate mudstones (Fig. 3). Bulk carbonate analyses are therefore considered to represent the total biogenic carbonates, i.e. foraminifers and calcareous nannofossils and exported neritic carbonate mud, predominantly reflecting a surface water signal. Samples were recovered from up to $15 \mathrm{~cm}$ below the surface, to minimize the effects of surface weathering. Bulk samples (and belemnites) were analysed at Plymouth University for carbon and oxygen stable isotopes. Using 200 to 300 micrograms of carbonate, stable isotope data were generated on a VG Optima mass spectrometer with a Gilson autosampler. Isotope ratios were calibrated using NBS19 standards and are given in $\delta$ notation relative to the Vienna Pee Dee 
Belemnite (VPDB). Reproducibility was generally better than $0.1 \%$ for samples and standard materials. Selected samples were also analyzed at SONATRACH (Algeria), for Total Organic Carbon (TOC). The calcium carbonate $\left(\mathrm{CaCO}_{3}\right)$ content for each bulk carbonate sample was performed using Bernard calcimeter at Cadi Ayyad University, Morocco. A number of belemnite samples were also analysed. These were typically somewhat fragmentary, making the identification of genera represented problematic. Where identifiable, ?Passaloteuthis was present, consistent with Sanders et al. (2013). Polished thin sections were used to undertake initial diagenetic screening using a MK5 CITL cathodoluminescence (CL) instrument (Fig. 4). The preservation of the belemnite rostra was also assessed using trace element analysis (Ca, Sr, Mg, Fe and Mn concentrations). The belemnites were prepared for stable isotope and trace element analysis by first removing the areas of the rostrum typically most prone to diagenesis (the rostrum exterior, apical region, alveolus and observable cracks/fractures). The remaining calcite was then fragmented, washed in pure water and dried in a clean environment. Fragments were subsequently picked under a binocular microscope to secure those judged to be best preserved, which were then analyzed for oxygen and carbon isotopes. The sub-samples taken for trace element analysis were digested in $\mathrm{HNO}_{3}$ and analysed by Inductively Coupled Plasma-Atomic Emission Spectrometer (ICP-AES) using a PerkinElmer 3100 at Plymouth University. Based upon analysis of duplicate samples reproducibility was better than $\pm 3 \%$ of the measured concentration of each element. Repeat analyses of standards JLS-1 and BCS CRM 393 was within $2 \%$ of the certified values for Sr, Mn, Ca and Mg and 10\% for Fe.

\section{Results}

\subsection{Lithology and stratigraphy}


132 Marmoucha, in the Middle Atlas (N 33²6'55.56" ; W 4²0'33.83") (Fig.2). The section begins with centimeter thick of limestone-marl alternations (equivalent of the Ouchbis Formation of the High Atlas). The limestone beds are typically wackestone-packstones, and contain a rich ammonite 135 fauna, with also belemnites, echinoids and brachiopods. Foraminifera (Bejjaji, 2007; Bejjaji et al., 2010) suggested a Late Pliensbachian age. The Lower Toarcian succession starts with green marls and marl-limestone alternations, rich in foraminifera, belemnites, echinoids and gastropods. The limestone beds are mudstone-wackestones (Figs. 3, 4). The Toarcian deposits are generally hemipelagic and correspond to basin environments (Reolid et al., 2013). The biostratigraphic framework of the Issouka section and the Middle Atlas has been established with ammonites (Benshili, 1989; Sabaoui, 1998; El Hammichi et al., 2008) and benthic foraminifera (Bejjaji, 2007; Bejjaji et al., 2010). For example, the occurrence of the benthic foraminifera Lenticulina sublaevis in the Middle Atlas is correlated by Bejjaji et al., (2010) to the Emaciatum ammonite zone of the Pliensbachian, whilst Lenticulina bochardi and Lenticulina toarcense are correlated with the Toarcian Polymorphum Zone and Lenticulina obonensis with the Serpentinus Zone. With respect to ammonites of the Middle Atlas, Emaciaticeras emaciatum of the Emaciatum Zone, Dactylioceras polymorphum of the Toarcian Polymorphum Zone and Hildaites levisoni and the Semicelatum Zone have also been identified (e.g. Benshili, 1989; El Hammichi et al., 2008; Bejjaji et al., 2010). Importantly, the lowermost Toarcian Polymorphum Zone is recognized, which has been taken as age equivalent to the Tenuicostatum Zone of NW Europe (e.g. Hesselbo et al., 2007; Reolid et al., 2012).

\subsection{Geochemistry}


155 The bulk carbon isotope data range from -1.8 to $+2.0 \%$. The carbon isotope curve shows a large (4

\%o) negative (stepwise) shift in the lower part of the section (Fig. 5), across the Upper

157 Pliensbachian-Lower Toarcian boundary. The most negative value $(-1.8 \%$ ) is seen within the lower 158 part of Polymorphum Zone. The sediment thickness recording this negative excursion is $15 \mathrm{~m}$.

159 Thereafter the bulk carbon isotope values return to pre-excursion values, around $+1.0 \%$, in the 160 upper part of the Polymorphum Zone and into the Serpentinus Zone. The oxygen isotope data 161 derived from the limestone and marls of the Pliensbachian and Toarcian show negative values that vary between -2.3 to $-6.5 \%$. Whilst the preservation of primary $\delta^{13} \mathrm{C}$ values during carbonate diagenesis is quite typical, fluid-rock interactions commonly result in a change in oxygen isotope

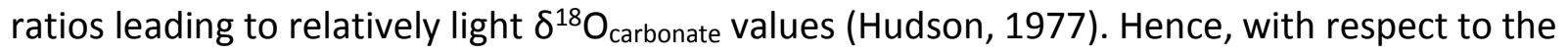
oxygen isotope data, a diagenetic overprint affecting the samples analysed is more likely. The oxygen isotope data are therefore not considered any further. The $\mathrm{CaCO}_{3}$ content shows values near $100 \%$ within the latest Pliensbachian and drop to $15-40 \%$ in the lowermost Toarcian, before increasing again in the upper part of Polymorphum Zone. The TOC data (Fig. 5) reveal low absolute values between $0.1 \%$ to $0.7 \%$ TOC. as well as in Table 1. Elemental concentrations were as follows: $\mathrm{Sr}$ ( 665 to 1194ppm); Mn (4 to 460 ppm); Mg (1210 to 3475 ppm) and Fe (10 to 2859 ppm) and Ca (26.7 to 45.4\%). The geochemical study of the belemnites reveals that they are typically well preserved, consistent with CL images, which show that the belemnites sampled in this study were largely non-luminescent (Fig. 4). Some 175 areas were revealed to be $\mathrm{Mn}$-rich and partial replacement by diagenetic calcite was observed particularly along the outermost growth bands and adjacent to the alveolar region. Despite some 
Table 1), reliable isotopic data from non-recrystallized shells of belemnites from the High Atlas are presented, showing little effects of substantial diagenetic changes associated with burial (cf. Lachkar et al., 2009). Positive carbon isotope values are recorded from the lowermost part of the section up to $+2.8 \%$. No marked shift towards lower carbon isotope values is seen across the boundary Pliensbachian-Toarcian. The positive values derived from the belemnites are seen within the lower part of Polymorphum Zone (and coincident with the negative carbon values derived from bulk analyses). The oxygen isotope data derived from the Pliensbachian belemnites range from (-

1.2 to $0.0 \%$ o). These data are considerably more positive that those data derived from the bulk rock analysis.

\section{Discussion}

5.1. Correlation of the negative carbon isotope excursion at Issouka with other sections

In accord with existing Jurassic carbon isotope curves, the Pliensbachian-Toarcian boundary is characterized by a negative excursion within the Polymorphum Zone (Hesselbo et al., 2007; Littler et al., 2010; Suan et al., 2011; Reolid et al., 2012), recorded in marine bulk-rock carbonates, brachiopods, wood and organic matter. This excursion coincides with major marine biological changes and extinction (Wignall et al., 2005; Wignall and Bond, 2008; Mattioli et al., 2009; Dera et al., 2010, Reolid et al., 2012) and an increase in temperature (e.g. Jenkyns et al. 2002; Rosales et al., 2004 ; Dera et al., 2011) culminating in the Falciferum Zone. shows some noteworthy similarities with data from the Amellago section (Bodin et al., 2016) and Bou Oumardoul/Toskine sections, Dades Valley (Krencker et al., 2015) also from the High Atlas (Fig. 6). In contrast, Bodin et al. (2016) show that the uppermost Pliensbachian is characterised by a 
201 gentle decreasing trend in $\delta^{13} C_{\text {org }}$ values, followed by an overall positive trend within the

202 Polymorphum Zone. The Issouka section is relatively expanded compared to the well-studied

203 European sections. Within the European sections where the Pliensbachian-Toarcian boundary

204 excursion is observed e.g. the Hawsker Bottoms section, Yorkshire, England (Littler et al., 2010), the

205 Mochras Farm Borehole (Jenkyns and Clayton, 1997) and Peniche, Portugal (Hesselbo et al., 2007)

206 the negative excursion is typically $2 \%$. As shown by Littler et al. (2010), this negative shift is

207 recorded within a relatively thin interval (Fig. 6). This could be the result of a short-lived episode or 208 alternatively sedimentary condensation. Littler et al. (2010) for example noted the abrupt onset of 209 the isotope excursion at Hawsker Bottoms and the initiation of an extinction step near the same 210 level, supporting the notion of a catastrophic event such as release of methane hydrate.

211 Alternatively it could equally be argued that the sections in Yorkshire and Peniche are

212 stratigraphically condensed (Fig. 6) or incomplete at this level. Nevertheless, the duration and pace 213 of onset of the event is unclear (Littler et al., 2010). Bodin et al. (2011), however, recorded the 214 event in an interval from the Amellago section of a few 10's of meters. They suggested the duration 215 is likely to be similar to the Early Toarcian Event and the Pliensbachian-Toarcian boundary negative 216 excursion was inadequately recorded in the more condensed sediments in Europe. The greater 217 magnitude of the event at Issouka is considered to be related to the expanded nature of the section 218 (e.g. when compared to the Europe sections) allowing sampling of the full magnitude of the event 219 as well as the stepwise character of the excursion. This stepwise character is certainly reminiscent 220 of the Toarcian event (e.g. Kemp et al., 2005; Hesselbo and Pieńkowski, 2011). 
The similarities of the Pliensbachian-Toarcian boundary negative excursion and the Early

225 Toarcian Event have been noted elsewhere (e.g. Suan et al., 2008; Krencker et al., 2015). An

extinction among different faunal groups has also been associated with both events. Carbon-

isotope records across the Late Pliensbachian to Early Toarcian interval show similarities between

the Middle and High Atlas and Peniche (Hesselbo et al., 2007) and Hawsker Bottoms sections

(Littler et al., 2010), in materials ranging from organic-matter, fossil-wood and bulk carbonate has

been taken to strongly suggest that the carbon cycle perturbation is at least a regional (e.g. Bodin et

al., 2010). Indeed, Hesselbo et al. (2007) suggested that the fossil-wood record from Peniche

indicates that the perturbation must have affected the atmospheric as well as the marine carbon reservoir (c.f. Bodin et al., 2016).

As the excursion at the Pliensbachian-Toarcian boundary is similar to the negative Early recycled in a restricted basin, is potentially inconsistent with the absence of light values derived 
recorded light isotope values or if they were surface dwellers they would recorded the isotopic composition of the overturning of a stratified water mass. To resolve this inconsistency the belemnites need to inhabit waters characterised by a DIC with 'normal' carbon-isotope compositions, and they only later migrate into the Middle Atlas area where they became fossilised. Alternatively, the belemnites flourished during brief events, and so captured a record of conditions only during these times, whilst the longer term oceanic conditions is represented by the sediment in which they are buried. These sediments carry a different isotopic record. It is difficult to determine whether a clear carbon isotope excursion across the Late Pliensbachian-Early Toarcian interval is seen in other macrofossil records. For example, the brachiopod data of Suan et al. (2010) showed a range of positive and negative values associated with the boundary interval, whilst belemnites precisely coinciding with the negative excursion at Peniche have yet to be isotopically analysed (Littler et al., 2010). A possible hint of a negative carbon isotope excursion across the Late Pliensbachian-Early Toarcian interval is also seen in the belemnite-derived data of Korte and Hesselbo (2011) from Yorkshire, UK.

The palaeotemperature record from the Late Pliensbachian-Early Toarcian interval could be used to inform which mechanism is applicable to the boundary event. The oxygen isotope values from the belemnite calcite show, however, no distinct trend across the event, indicative of either no significant change in temperatures or a change in seawater $\delta^{18} \mathrm{O}$. Since upwelling should lead to cooler temperatures and a massive methane dissociation should be associated with a temperature maximum, the belemnite ${ }^{18} \mathrm{O}$ data support neither of these mechanisms. Likewise, $\delta^{18} \mathrm{O}_{\text {belemnite }}$ records from Spain show a gradual decrease in oxygen isotope values in the latest Pliensbachianearliest Toarcian, which indicates warming (e.g. Rosales et al. 2004). The oxygen isotope data of brachiopods from Peniche of Suan et al. (2010) also showed lighter values associated with the 
271

272

boundary possibly linked to warming. Other studies, however, have showed the opposite trend (Harazim et al., 2013), which could be interpreted as falling temperatures.

Notably Littler et al. (2010) considered the release of isotopically light thermogenic methane (McElwain et al., 2005) as a possible mechanism driving the Late Pliensbachian-Early Toarcian carbon isotope excursion. As peak lava emplacement for the Karoo region coincided with the Pliensbachian-Toarcian boundary it is possible that a pulse of thermogenic methane from this region could be partly responsible for the excursion (Littler et al., 2010). Bearing in mind the positive carbon values derived from the belemnites, any effect of the explosive release of metamorphic thermogenic methane needs to have resulted in spatial variability in the $\delta^{13} \mathrm{C}$ of the DIC of seawater. The surface ocean $\delta^{13} C_{D I C}$ is required to drop, possibly owing to relatively slow vertical mixing, whilst deeper sea $\delta^{13} C_{D I C}$ remains constant ('normal'), as reflected in the positive carbon values derived from the belemnites. Although the atmosphere and surface ocean carbon reservoirs would have responded almost immediately to an initial release of light carbon, because of the slower mixing time of the deep ocean ( 1,500 years), it should take several thousands of years for the full magnitude of the carbon isotope excursion to be manifested in the deeper ocean water masses. Given the likely duration of the Polymorphum Zone (0.9-1.0 myr, Martinez et al., 2016), mixing and equilibration should, however, have taken place prior to when those more belemnites recording the most positive carbon isotopes lived and were deposited.

Alternatively, Bodin et al. (2016) have recently suggested a lithological, rather than oceanographical control on $\delta^{13} \mathrm{C}$ trends, whereby neritic $\delta^{13} \mathrm{C}_{\text {micrite }}$ signatures show more positive values than carbonate ooze produced by planktonic organisms (e.g. Swart and Eberli, 2005). Hence the loss of exported neritic mud, for example during the earliest Toarcian, could lead to a negative shift in the $\delta^{13} C_{\text {micrite }}$ signature without any relation to variations in the global carbon isotope trend (Bodin et al., 2016, see also Martinez et al., 2016). Given the correlation between $\mathrm{CaCO}_{3}$ content 
295 and the $\delta^{13} C_{\text {micrite }}$ shift across the Pliensbachian-Toarcian boundary (Fig. 5) a loss of exported 296 neritic mud, as a result of platform drowning could lead to the negative shift observed in the $297 \delta^{13} C_{\text {micrite. }}$ The belemnite record in this setting reflects the DIC of more open-ocean water masses. 298 Bodin et al. (2016) go on to suggest that given that their $\delta^{13} C_{\text {org }}$ record from the High Atlas is 299 mostly derived from continental organic matter, it reflects genuine changes in the atmospheric 300 carbon cycle. The $\delta^{13} \mathrm{C}_{\text {belemnite }}$ record of this study appearing to correlate with the Bodin et al. 301 (2016) $\delta^{13} \mathrm{Corg}$ record (Fig. 6), raises the possibility that belemnite carbon isotope data are also 302 tracking the atmosphere carbon cycle. Nevertheless, this scenario is difficult to reconcile with data 303 from more distal locations (e.g. Yorkshire, UK, Littler et al., 2010)

\section{Conclusions}

The carbon isotope curve obtained from the Issouka section (Middle Atlas, Morocco) displays a distinct negative shift at the Pliensbachian-Toarcian. This excursion coincides with a change in sedimentation and major marine biological changes and extinctions. This shift is correlated to the ones observed in well-documented European sections and thus further confirms, the supra-regional nature of perturbation in the oceanic carbon cycle. A regional change in the source of the carbonate carrying the isotope signal, could lead to a negative shift in the $\delta^{13} C_{\text {micrite }}$ 313 signature without any relation to variations in the global carbon isotope trend. However, as fossil314 wood records also showed the excursion the perturbation is considered to have affected the 315 atmospheric as well as the marine carbon reservoir. If the belemnite records of this study can be replicated elsewhere it may suggest that the entire water column was not affected by these carbon cycle changes, as would be anticipated if methane hydrate release was the mechanism. Likewise, 
overturning or upwelling of a stratified water mass requires the belemnites to have lived elsewhere and only later migrated into the Middle Atlas area where they became fossilized. Nevertheless, the belemnite $\delta^{13} \mathrm{C}$ data presented here suggests a more complex pattern and some spatial heterogeneity.

\section{Acknowledgements}

We would like to thank Nino Mariotti (Sapienza University) for the confirmation of

belemnite identification. This paper greatly benefited from 2 constructive reviews of Guillaume

326 Suan and Stéphane Bodin.

\section{References}

Bassoulet, J., Elmi, S., Poisson, F., Cecca, F., Belion, Y., Guiraud, R., Baudin, F., 1993. Mid Toarcian. In: Dercourt, J., Ricou, L.E., Vrielynck, B. (Eds.) Atlas Tethys, Paleoenvironmental Maps: Becip-Franlab, Rueil-Malmaison, France. 63-80.

Bejjaji, Z., 1994. Les foraminifères du Toarcien du Moyen Atlas Central(Maroc), micropaléontologie et paléoenvironnements. Thèse 3éme cycle, Univ. Mohammed V, Rabat (Thèse 3ème cycle,Univ. Mohammed V,) 231.

Bejjaji, Z., 2007. Biostratigraphie, paléoenvironnements et paléoécologie des foraminifères toarciens du Moyen Atlas. PhD Thesis Université Mohammed V, Rabat 1-231.

Bejjaji, Z., Chakiri, S., Reolid, M., Boutakiout, M., 2010. Foraminiferal biostratigraphy of the Toarcian deposits (Lower Jurassic) from the Middle Atlas (Morocco). Comparison with western Tethyan areas. Journal of African Earth Sciences 57, 154-162. 
Benshili, K., 1989. Lias-Dogger du Moyen Atlas plissé (Maroc) sédimentologie, biostratigraphie et évolution paléogéographique. Documents des Laboratoires de Géologie Lyon 106, 1-285.

Blomeier, D.P.G., Reijmer, J.J.G., 1999. Drowning of a Lower Jurassic Carbonate Platform: Jbel Bou Dahar, High Atlas, Morocco. Facies 41, 81-110.

Bodin, S., Mattioli, E., Fröhlich, S., Marshall, J.D., Boutib, L., Lahsini, S., Redfern, J., 2010. Toarcian carbon isotope shifts and nutrient changes from the Northern margin of Gondwana (High Atlas, Morocco, Jurassic): Palaeoenvironmental implications. Palaeogeography, Palaeoclimatology, Palaeoecology 297, 377-390.

Bodin, S., Fröhlich, S., Boutib, L., Lahsini, S., Redfern, J., 2011. Early Toarcian source-rock potential in the Central High Atlas Basin (central Morocco): Regional distribution and depositional model. Journal of Petroleum Geology 34, 345-364.

Bodin, S., Krencker, F., Kothe, T., Hoffmann, R., Mattioli, E., Heimhofer, U., Kabiri, L., 2016. Perturbation of the carbon cycle during the late Pliensbachian - Early Toarcian: New insight from high-resolution carbon isotope records in Morocco. Journal of African Earth Sciences 116, 89-104.

Cecca, F., Macchioni, F., 2004. The two Early Toarcian (Early Jurassic) extinction events in ammonoids. Lethaia 37, 35-56.

Charriere, A., 1990. Héritage hercynien et évolution géodynamique alpine d'une chaine intracontinentale: le Moyen Atlas au SE de Fès(Maroc). Thèse d'Etat, Univ.Paul Sabatier,Toulouselll (Sciences),2 tomes 589.

Cohen, A.S., Coe, A.L., Harding, S.M., 2004. Osmium isotope evidence for the regulation of atmospheric $\mathrm{CO} 2$ by continental weathering. Geology 32, 157-160.

Cohen, A.S., Coe, A.L., Kemp, D.B., 2007. The Late Palaeocene-Early Eocene and Toarcian (Early Jurassic) carbon isotope excursions: a comparison of their time scales, associated 
environmental changes, causes and consequences. Journal of the Geological Society of London 164, 1093-1108.

Dera, G., Pellenard, P., Neige, P., Deconinck, J.-F., Pucéat, E., Dommergues, J.-L., 2009. Distribution of clay minerals in Early Jurassic Peritethyan seas: Palaeoclimatic significance inferred from multiproxy comparisons. Palaeogeography, Palaeoclimatology, Palaeoecology 271, $39-51$.

Dera, G., Neige, P., Dommergues, J.-L., Fara, E., Laffont, R., Pellenard, P., 2010. High resolution dynamics of Early Jurassic marine extinctions: the case of Pliensbachian-Toarcian ammonites (Cephalopoda). Journal of Geological Society of London $167,21-33$.

Dera, G., Brigaud, B., Monna, F., Laffont, R., Pucéat, E., Deconinck, J.-F., Pellenard, P., Joachimski, M., Durlet, C., 2011. Climatic ups and downs in a disturbed Jurassic world. Geology 39, $215-218$.

Du Dresnay, R., 1971. Extension et developement des phenomenes recifaux Jurassique dans le domaine Atlasique Marocain, particulierement au Lias moyen. Bulletin de la Société Géologique de France 13, 46-56.

El Arabi, H., Ouahhabi, B., Charrière, A., 2001. Les séries du Toarcien-Aalénien du SW du MoyenAtlas (Maroc): précisions stratigraphiques et signification paléogéographique. Bulletin de la Société Géologique de France 172, 723-736.

El Hammichi, F., Benshili, K., Elmi, S. 2008, Les faunes d'Ammonites du Toarcien-Aalénien du Moyen Atlas sud-occidental (Maroc). Revue de Paléobiologie, 27, 429-447.Ettaki, M., Chellai, E.H., Milhi, A., Sadki, D., Boudchiche, L., 2000. Le passage Lias moyen-Lias superieur dans la region de Todrha-Dades: environments bio-sedimentaires et geodynamiques (Haut Atlas central, Maroc) . Comptes Rendus de I'Academie des Sciences - Series IIA 331, 667674. 
Ferreira, J., Mattioli, E., Pittet, B., Cachão, M., Spangenberg, J.E., 2015. Palaeoecological insights on Toarcian and lower Aalenian calcareous nannofossils from the Lusitanian Basin (Portugal): Palaeogeography, Palaeoclimatology, Palaeoecology, 436, 245-262.

Hallam, A., 1997. Estimates of the amount and rate of the of sea level change across the RhaetianHettangian and Pliensbachian-Toarcian boundary (latest Triassic to Early Jurassic ) . Journal of the Geological Society of London 154, 773-779.

Harazim, D., van de Schootbrugge, B., Sorichter, K., Fiebig, J., Weug, A., Suan, G., Oschmann, W., 2013. Spatial variability of watermass conditions within three European epicontinental seaways during the Early Jurassic (Pliensbachian-Toarcian). Sedimentology 60, 359-390.

Hardenbol, J., Thierry, J., Farley, M.B., Jacquin, T. de Graciansky, P.C., Vail, P., 1998. Mesozoic and Cenozoic sequence chronostratigraphic framework of European basins, in P.C. Graciansky, et al. (eds) Mesozoic and Cenozoic Sequence Stratigraphy of. European Basins: SEPM Special Publication 60, 3-13.

Harries, P.J., Little, C.T.S., 1999. The Early Toarcian (Early Jurassic) and the Cenomanian-Turonian (Late Cretaceous) mass extinctions: similarities and contrasts. Palaeogeography Palaeoclimatology Palaeoecology 154, 39-66.

Hermoso, M., Le Callonnec, L., Minoletti, F., Renard, M., Hesselbo, S.P., 2009. Expression of the Early Toarcian negative carbon-isotope excursion in separated carbonate microfractions (Jurassic, Paris Basin). Earth and Planetary Science Letters 277, 194-203.

Hesselbo, S.P., Gröcke, D.R., Jenkyns, H.C., Bjerrun, C.J., Farrimond, P., Morgans Bell, H.S., Green, O.R., 2000. Massive dissociation of gas hydrate during a Jurassic oceanic anoxic event. Nature 406, 392-395. 
Hesselbo, S.P., Jenkyns, H.C., Duarte, L.V., Oliveira, L.C.V., 2007. Carbon-isotope record of the Early Jurassic (Toarcian) Oceanic Anoxic Event from fossil wood and marine carbonate (Lusitanian Basin, Portugal). Earth and Planetary Science Letters 253, 455-470.

Hesselbo, S.P., Pienkowski, G., 2011. Stepwise atmospheric carbon isotope excursion during the Toarcian Oceanic Anoxic Event (Early Jurassic, Polish Basin). Earth and Planetary Science Letters 301, 365-372.

Hudson, J.D., 1977. Stable isotopes and limestone lithification. Journal of the Geological Society of London 133, 637-660.

Jenkyns, H.C., Clayton, C.J., 1997. Lower Jurassic epicontinental carbonates and mudstones from England and Wales: chemostratigraphic signals and the early Toarcian anoxic event. Sedimentology 44, 687-706.

Jenkyns H.C., Jones, C., Gröcke, D., Hesselbo S.P., 2002. Chemostratigraphy of the Jurassic System: applications, limitations and implications for palaeoceanography. Journal of Geological Society of London 159, 351-378.

Kemp, D.B., Coe, A.L., Cohen, A.S., Schwark, L., 2005. Astronomical pacing of methane release in the Early Jurassic period. Nature 437, 396-399.

Krencker, F.-N., Bodin, S., Suan, G., Heimhofer, U., Kabiri, L., Immenhauser, A., 2015. Toarcian extreme warmth led to tropical cyclone intensification. Earth and Planetary Science Letters $425,120-130$.

Küspert, W., 1982. Environmental changes during oil shale deposition as deduced from stable isotope ratios, in Cyclic and Event Stratification. G. Einsele and A. Seilacher. (Eds) Springer, Berlin 482-501.

Lachkar, N., Guiraud, M., El Harfi, A., Dommergues, J.-L., Dera, G., Durlet, C., 2009. Early Jurassic normal faulting in a carbonate extensional basin: characterization of tectonically driven 
platform drowning (High Atlas rift, Morocco) . Journal of Geological Society of London $166,413-430$.

Laville, E., Pique, A., Amrhar, M., Charroud, M., 2004. A restatement of the Mesozoic Atlasic Rifting (Morocco). Journal of African Earth Sciences 38, 145-153.

Little, C.T.S., Benton, M.J., 1995. Early Jurassic mass extinction: a global long-term event. Geology $23,495-498$.

Littler, K., Hesselbo, S.P., Jenkyns, H.C., 2010. A carbon-isotope perturbation at the PliensbachianToarcian boundary: evidence from the Lias Group, NE England. Geological Magazine $147,181-192$.

Martinez, M., Krencker, F.-N., Mattioli E., Bodin, S. 2016. Orbital chronology of the Pliensbachian Toarcian transition from the Central High Atlas Basin (Morocco). Newsletters on Stratigraphy,

Mattioli, E., Pittet, B., Petitpierre, L., Mailliot, S., 2009. Dramatic decrease of pelagic carbonate production by nannoplankton across the Early Toarcian Anoxic Event (T-OAE). Glob. Planet. Change 65, 134-145.

McElwain, J. C., Wade-Murphy, J., Hesselbo S.P., 2005. Changes in carbon dioxide during an oceanic anoxic event linked to intrusion into Gondwanan coals. Nature 435,479-482.

Michard, A., 1976. Eléments de géologie Marocaine. Notes et Mémoires du Service Géologique 252, 408.

Montero-Serrano, J.C., Föllmi, K., Adatte T., Spangenberg J.E., Tribovillard, N., Fantasia, A., Suan, G., 2015. Continental weathering and redox conditions during the early Toarcian Oceanic Anoxic Event in the northwestern Tethys: Insight from the Posidonia Shale section in the Swiss Jura Mountains. Palaeogeography, Palaeoclimatology, Palaeoecology 429, 83-99. 
Porter, S.J., Smith, P.L., Caruthers, A.H., Pengfei, H., Gröcke, D,R., Selby, D. 2014. New high resolution geochemistry of Lower Jurassic marine sections in western North America: A global positive carbon isotope excursion in the Sinemurian? Earth and Planetary Science Letters 397, 19-31.

Reolid, M., Martínez-Ruiz, F. 2012. Comparison of benthic foraminifera and geochemical proxies in shelf deposits from the Upper Jurassic of the Prebetic (southern Spain). Journal of Iberian Geology 38, 449-465.

Reolid, M., Chakiri, S., Bejjaji, Z., 2013. Adaptative strategies of the Toarcian benthic foraminiferal assemblages from the Middle Atlas (Morocco): Palaeoecological implications. Journal of African Earth Sciences 84, 1-12.

Rosales, I., Robles, S., Quesada, S., 2004. Elemental and oxygen isotope composition of early Jurassic belemnites: Salinity vs. temperature signals. J. Sediment. Res 74,342-354.

Ruget, Ch., Nicollin, J.P., 1997. Les petites foraminifères benthiques dégagés. In: Cariou, E., Hantzpergue, P. (Eds.),Biostratigraphie du Jurassique Ouest-European et Mediterranen, Bull. Centre Rech. Elf Explor. Prod. Mem, 17, 281-291.

Sabaoui, A., 1998. Rôle des inversions dans l'évolution Méso-Cénozoïques du Moyen Atlas septentrional (Maroc). L'exemple de la transversale El Menzel-Ribat El Khayr-Bou Iblane. PhD Thesis, Université Mohammed V Rabat, 1-432.

Sandoval, J., Bill, M., O’Dogherty, L., Rivas, P., Morard, A., Guex, J. 2012. The Toarcian in the Subbetic basin (southern Spain): bioevents (ammonite and calcareous nannofossils) and carbon-isotope stratigraphy. Palaeogeography Palaeoclimatology, Palaeoecology 342$434,40-63$. 
Sanders, M.T., Bardin, J., Benzaggagh , M., Cecca, F., 2013. Early Toarcian (Jurassic) belemnites from northeastern Gondwana (South Riffian ridges, Morocco). Paläontologische Zeitschrift, DOI 10.1007/s12542-013-0214-0

Souhel, A., Canerot, J., El Bchari, F., Chafiki, D., Gharib, A., El Hariri, K., Bouchouata, A., 2000. The Liassic carbonate platform on the western part of the Central High Atlas (Morocco): stratigraphic and palaeogeographic patterns. In: Crasquin-Soleau, S., Barrier, E. (Eds.), Peri-Tethys Memoir 5: new data on Peri-Tethyan sedimentary. Paris 39-56.

Studer, M., Du Dresnay, R., 1980. Deformations synsedimentaires en compression pendant le Lias superieur et le Dogger, au Tizi n'Irhil (Haut Atlas central de Midelt, Maroc). Bulletin de la Société Géologique de France, 22, 391-397.

Suan, G., Pittet, B., Bour, I., Mattioli, E., Duarte, L.V., Mailliot, S., 2008. Duration of the Early Toarcian carbon isotope excursion deduced from spectral analysis: consequence for its possible causes. Earth and Planetary Science Letters 267, 666-679.

Swart, P.K., Eberli, G.P., 2005. The nature of the $\delta^{13} \mathrm{C}$ of periplatform sediments: Implications for stratigraphy and the global carbon cycle. Sediment. Geol. 175, 115-129.

Suan, G., Mattioli, E., Pittet, B., Lécuyer, C., Suchéras-Marx, B., Duarte, L.V., Philippe, M., Reggiani, L., Martineau, F., 2010. Secular environmental precursors to Early Toarcian (Jurassic) extreme climate changes. Earth and Planetary Science Letters 290, 448-458.

Suan, G., Nikitenko, B.L., Rogov, M.A., Baudin, F., Spangenberg, J.E., Knyazev, V.G., 2011. Polar record of Early Jurassic massive carbon injection. Earth and Planetary Science Letters 312, $102-113$.

Wignall, P.B., Newton, R.J., Little, C.T.S., 2005. The timing of paleoenvironmental change and cause-and-effect relationships during the early Jurassic mass extinction in Europe. American Journal of Science 305, 1014-1032. 
503 Wignall, P.B., Bond, D.P.G., 2008. The end-Triassic and Early Jurassic mass extinction records in the 504 British Isles. Proceedings of the Geologists' Association 119, 73-84.

505 Wilmsen, M., Neuweiler, F., 2008. Biosedimentology of the Early Jurassic postextinction carbonate 506 depositional system, central High Atlas rift basin, Morocco. Sedimentology 55, 773-807. 507 508 


\section{Figure Captions}

511 Figure 1. (a) Toarcian palaeogeographic map, Western Tethyan realm (modified after Bassoulet et al., 1993), with localities; 1-Issouka, 2-Peniche, 3-Mochras Farm(b) Simplified structural map of Morocco, with position of the Issouka section and the Amellago section (of Bodin et al., 2010) and

514 Bou Oumardoul section (of Krencker et al., 2015) (modified after Lachkar et al., 2009). Grey inset 515 box shows location of Figure 2.

Figure 2. Geological map of the Middle Atlas and section locality (modified from Bejjaji et al., 2010)

Figure 3. The different facies in the Issouka section. (a). Limestones of the Late Pliensbachian with showing abundance of microfauna - wackestone texture. (c) The Lower Toarcian, characterized by grey marls at the boundary and limestone intercalation. (d) Photomicrograph showing the marls of 523 the Lower Toarcian - a mudstone texture with quartz grains.

Figure 4 (a) CL and (b) PPL photomicrographs of belemnite rostrum (Sample IS8) exhibiting a minor degree of luminescence associated with central apical zone (c) $C L$ and (d) photomicrographs of 527 belemnite rostrum (IS6B1) exhibiting a modest luminescence associated with central apical zone (e) $528 \mathrm{CL}$ and (f) PPL photomicrographs of belemnite margin (sample IS3) showing highly luminescence 529 mudstone adjacent to the rostrum margin exhibiting minor luminescence. 
531 Figure 5. $\mathrm{CaCO}_{3}, \mathrm{TOC}$ data and isotopic results from the Issouka section. $\delta^{13} \mathrm{C}$ and $\delta^{18} \mathrm{O}_{\text {micrite }}$ (grey

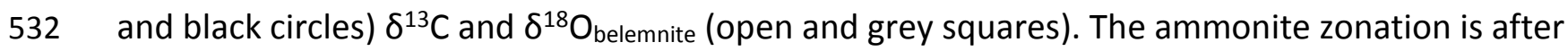
533 (Benshili, 1989; Sabaoui, 1998; El Hammichi et al., 2008).

534

535 Figure 6. Carbon isotope stratigraphies at the Pliensbachian-Toarcian boundary from the Issouka 536 section compared with the Amellago (Bodin et al., 2010; Bodin et al., 2016) and the Bou 537 Oumardoul sections, High Atlas (Krencker et al., 2015; Bodin et al., 2016); the Peniche section, 538 Portugal (Hesselbo et al., 2007; Littler et al. 2010) and the Mochras Farm borehole (Wales; Jenkyns 539 and Clayton, 1997).

540

541 Table 1 Isotopic and elemental compositions of belemnites analysed in this study. 